\title{
Transnational Governance, Local Politics, and Gender Violence Law in Nicaragua
} Pamela J. Neumann

\begin{abstract}
Many Latin American countries have passed laws intended to address femicide and other forms of violence against women. Yet the implementation of these laws has been inconsistent at best. This article analyzes the case of Nicaragua, which passed a comprehensive law on gender-based violence (Law 779) in 2012. While celebrated by local women's organizations, Law 779 was subsequently weakened through a series of legislative reforms and executive decrees. This article seeks to explain why state actors in Nicaragua initially supported Law 779 and later sought to undermine it. It argues that in contexts characterized by a high concentration of political power like Nicaragua, transnational governance structures are insufficient to ensure the success of gender violence legislation. Through an analysis of Law 779 , this article contributes to broader debates about the nature of state legitimacy and the potential of legal advocacy to address violence against women.
\end{abstract}

Keywords: gender, law, transnational, violence, Nicaragua

$\mathrm{D}$ espite the passage of numerous laws addressing gender-based violence throughout Latin America (and worldwide), impunity for crimes against women remains a widespread problem (ECLAC 2014; Fregoso and Bejarano 2010; Staudt 2008; Walsh and Menjívar 2016). The global consensus on the importance of eliminating violence against women has been insufficient to bridge the gap between lofty legal texts and everyday practices in the criminal justice system in many Latin American countries (Friedman 2009; Neumann 2017). Yet legal reforms remain one of the primary strategies employed by local and transnational feminist groups, as well as international development organizations, for reducing violence against women. Although legislation is a crucial vehicle for codifying women's rights and providing a basis for women's legal claims, the mere existence of laws frequently does not translate into tangible improvements to women's safety or access to legal justice (Franceschet 2010; Sagot 2005; Walsh and Menjívar 2016). To understand why this is the case, more attention to the trajectory of particular laws on gender violence is needed.

With these concerns in mind, this article examines the case of Law 779, Nicaragua's most recent gender violence law, passed in 2012. Law 779 expanded defi-

Pamela J. Neumann is a postdoctoral fellow at the Stone Center for Latin American Studies, Tulane University.pneuman@tulane.edu 
nitions of violence against women, increased carceral penalties, established new protective measures for women victims, and eliminated the controversial practice of informal mediation. Local women's organizations celebrated Law 779, but the legislation faced an immediate backlash from conservative and religious sectors, which argued that it was an attack on "family values" and discriminatory against men. The contentious debate over the law was reflected in extensive local newspaper coverage. Between June 2012 and December 2013, more than 250 news and opinion pieces praising or critiquing Law 779 were published in Nicaragua, a rate of nearly 13 articles per month.

Amid this heated discursive debate, feminist organizations and religious groups took to the streets - the former to demand the implementation of the law, the latter to repeal it. Just 14 months after the original law was approved, in July 2013, the National Assembly passed an amended version, significantly weakening legal protections for women. A further rollback of the law occurred in August 2014 when President Daniel Ortega signed a decree mandating that women seek "family counseling" from neighborhood councils before reporting violence to the police.

Why did state actors in Nicaragua initially support this progressive legislation on violence against women and later undermine it? Examining both the regional and local political context is crucial to answering this question. More specifically, between 2012, when Law 779 was passed, and 2014, when it was irrevocably weakened, the political calculus of the Ortega government changed dramatically. This article argues that Law 779 was initially passed in order to enhance the Nicaraguan state's legitimacy by following regional trends on violence against women and drawing attention away from President Ortega's unconstitutional re-election in 2011. By 2014, however, changing local and regional dynamics meant that President Ortega was more concerned with preserving his instrumental alliance with conservative religious groups and Nicaragua's reputation as the "safest country in Central America." ${ }^{1}$ Through an analysis of the trajectory of Law 779 , this article contributes to broader debates about state legitimacy and the limitations of transnational legal activism in addressing gender violence.

\section{MethodologY}

This article is based on ethnographic data collected between June 2012 and December 2014, a systematic analysis of more than four hundred newspaper articles published in the Nicaraguan press between 2010 and 2015, and publicly available government records.

To analyze newspaper coverage of Law 779, Google tools were used to search the websites of three major Nicaraguan newspapers: La Prensa, El Nuevo Diario, and Confidencial. The following Spanish search terms were used to compile a comprehensive list of articles related to gender violence in Nicaragua: femicidio (femicide), Ley 779 (Law 779), género (gender), violencia (violence), violencia contra la mujer (violence against women), comisarias (women's police stations), policia (police), fiscallfiscalia (public prosecutor), juzgados especializados (specialized courts), movimiento feminista (feminist movement), movimiento de mujeres (women's movement). The 
Table 1. Events Attended Concerning Law 779

\begin{tabular}{ll}
\hline \hline Date & Event \\
\hline $6 / 16 / 2012$ & Feminist forum on Law 779 \\
$6 / 22 / 2012$ & Demonstration for Implementation of Law 779 \\
$7 / 10 / 2012$ & Neighborhood meeting about Law 779 \\
$7 / 11 / 2012$ & Neighborhood meeting about Law 779 \\
$5 / 28 / 2013$ & Women's movement protest at Supreme Court \\
$5 / 31 / 2013$ & Women's protest against reform of Law 779 \\
$6 / 14 / 2013$ & Women's demonstration against reform of Law 779 \\
$6 / 17 / 2013$ & Women's demonstration against reform of Law 779 \\
$6 / 26 / 2013$ & Meeting of Access to Justice and Violence Against Women \\
& Interinstitutional Commission \\
$7 / 1 / 2013$ & Seminar on Law 779 for Evangelical pastors \\
$7 / 10 / 2013$ & Training on Law 779 for Women Promoters \\
$7 / 14 / 2014$ & Women's movement press conference on Law 779 \\
$8 / 14 / 2014$ & Women's march against femicide \\
$8 / 21 / 2014$ & Meeting of Gender Equity Roundtable \\
$8 / 29 / 2014$ & United Nations Development Program-sponsored training for women's \\
& organizations on Law 779 \\
$10 / 1 / 2014$ & Inauguration of family counseling office \\
$10 / 30 / 2014$ & Nationwide training for women promoters and community leaders on \\
& Presidential Decree and Law 779 \\
\hline \hline
\end{tabular}

Note: All events took place in Managua.

compiled list of articles was categorized into statements by state officials, statements by local women's organizations, and statements by religious leaders. Open and focused coding was then used to identify the most prominent discursive themes. This article also draws on participant observation data gathered at 17 events related to Law 779 between 2012 and 2014. Table 1 provides a detailed list of these events.

\section{GENDER-BASED ViOLENCE, LAW, AND GLOBAL GOVERNANCE}

Violence against women became part of the global development and human rights agenda due to the persistent work of transnational feminist advocacy networks (Keck and Sikkink 1998). During the United Nations Decade for Women (197685), these networks gained increasing prominence through their participation in a series of global conferences, in which one of the key topics of discussion was the various forms of violence confronting women in their respective countries (Ferree and Tripp 2006; Friedman 2003; Joachim 2007). At the regional level, the Latin American and Caribbean Feminist Network Against Domestic and Sexual Violence (Sternbach et al. 1992) was also instrumental in drawing attention to the issue of gender violence and pressuring local governments to take action. 
In 1993, the United Nations issued its Declaration on the Elimination of Violence Against Women, and in 1994 the Organization of American States approved the Inter-American Convention on the Prevention, Punishment, and Eradication of Violence Against Women (Belém do Pará) (Bunch and Fried 1996; Charlesworth 1994). One of the major advances of these conventions was their definitions of violence against women (Bunch 1990). For example, the Belém do Pará Convention explicitly defined violence against women as any form of "physical, sexual, and psychological" violence committed by "any person" that is "perpetrated or condoned by the State" (Article II). By the end of the 1990s, every country in Latin America had ratified the Belém do Pará Convention (Friedman 2009).

The 1995 Beijing Platform for Action, adopted at the United Nations Fourth World Conference on Women, further specified that violence against women included "any act of gender-based violence that results in, or is likely to result in, physical, sexual or psychological harm or suffering to women, including threats of such acts, coercion or arbitrary deprivation of liberty, whether occurring in public or private life." Notably, this definition made violence committed against women in so-called private spaces a punishable offense. The Beijing Platform called on national governments to enact legislation to punish gender-based violence in the home, workplace, and community; provide state officials with specialized training; and ratify all related international agreements (Beijing Platform for Action 1995).

One hundred eighty-nine countries ratified the Beijing Platform, a somewhat surprising number, since no explicit consequences existed for failing to do so. ${ }^{2} \mathrm{How}$ ever, as Merry (2006) notes, there are indirect "political and economic dividends" (in the form of trade relations and foreign investment, for example) that states may receive in return for making these kinds of symbolic international commitments to human rights. In other words, countries may sign on to these agreements not necessarily because of their stance on violence against women per se but to maintain legitimacy and to mark their membership in the international community (Merry 2006).

While the ratification of these conventions came quickly, the kind of antiVAW legislation called for by the Beijing Platform was slower to come to fruition. This lack of legal action occurred arguably because the failure to abide by international agreements on VAW carried no real sanctions (Desai 2005). In theory, poorer nations with more vulnerable economies are more susceptible to international pressures - such as accepting the terms of loans from the International Monetary Fund. However, the consequences for ignoring international agreements on human rights are more symbolic. Thus, the global stakes, even for poorer nations like Nicaragua, are relatively low when it comes to addressing violence against women.

As Merry points out, documents like international conventions "define offenses and articulate desirable standards of behavior. But they do not contain rules whose infractions result in punishment of noncompliant nations" $(2006,228) .{ }^{3}$ Holding states accountable is further complicated by the fact that "many forms of domestic violence and sexual assault are perpetuated by private citizens rather than by states" (Merry 2006, 22). In countries where new legislation to advance women's rights did pass, cross-national research has shown that the decisive factor was not the interven- 
tion of multilateral institutions but the work of vibrant grassroots feminist movements (Htun and Weldon 2012). Such movements are critical, not only because they place pressure on states, but also because they can "translate" global human rights norms in culturally relevant ways, thereby countering accusations of "imperialistic intervention" and building local support for legal change (Figueroa and Barbeyto 2014; Merry 2006).

Thus, international consensus or pressure is a necessary but not sufficient condition for legal change to occur at the country level. Unless there are material consequences for failing to enforce international norms or high levels of domestic pressure, it seems unlikely that state actors will be moved. According to Andrew Byrnes, "international pressure' ... is often dependent on the geopolitics of states and can only work effectively when states wish to protect or maximize their own interests" (1994, cited in Grewal 1999, 343). Although highly mobilized feminist coalitions have effectively spurred progressive policy change on violence against women (Htun and Weldon 2012; Keck and Sikkink 1998), such pressure does not necessarily lead to changes in official state practice (Neumann 2017).

The Belém do Pará Convention (1994) spurred every democracy in Latin America to adopt a new law prohibiting domestic violence. Between 2001 and 2006, five countries strengthened their existing legislation (Friedman 2009). Sixteen countries now have femicide laws (Bernal Sarmiento et al. 2014). This wave of legislative activity on gender-based violence suggests the importance of regional actors like the Organization of American States, which contains an entire unit, the InterAmerican Commission on Women, dedicated to promoting the adoption and implementation of regional norms and practices for addressing violence against women However, states characterized by a high degree of consolidation of power are much more immune to both external and internal pressures (Amenta et al. 2010; Kitschelt 1986). Such is the case of Nicaragua.

\section{Configurations of Power IN NiCARAGUA}

Daniel Ortega, the Sandinista leader who governed Nicaragua during the postrevolutionary period (1979-90), returned to the presidency in 2007. His victory in the 2006 presidential election was a product of mounting antineoliberal sentiment, a divided opposition, and a favorable change in electoral law. ${ }^{4}$

Long before assuming the presidency in 2007, Ortega had begun to consolidate power through a series of strategic alliances. His ability to do so, as Martí i Puig and Wright note, was a function of broader changes in the FSLN that transformed the party from a political-military organization to a "centralized organization, totally faithful to its leader" $(2010,80) .^{5}$ These incremental changes were apparent as early as the mid-1990s and became a source of concern for several prominent members of the FSLN (including former vice president Sergio Ramírez and revolutionary hero Dora María Téllez), who publicly broke from the party and formed the Movimiento Renovador Sandinista (MRS) in 1995. In 1999, Ortega and former 
president Arnoldo Alemán (1997-2001) entered into a power-sharing agreement (known as el pacto) to divide control of Nicaragua's institutions between their two respective political parties, the FSLN and the PLC (Hoyt 2004). Under Alemán's successor, Enrique Bolaños (2001-6), Alemán was charged with embezzlement and placed under house arrest. A split in the PLC followed, and the Alianza Liberal de Nicaragua (ALN) was formed in 2005. The PLC-ALN split was a decisive factor that propelled Ortega back into office. ${ }^{6}$

Another influential factor leading to Ortega's victory was his alliance with the local Catholic Church hierarchy (Kampwirth 2011). In 2005, Ortega and his common-law partner, Rosario Murillo, were officially married in the Catholic Church in a highly publicized ceremony. This act cemented Ortega's alliance with his powerful longtime critic Cardinal Miguel Obando y Bravo, who was appointed head of the government's Peace and Reconciliation Commission following Ortega's victory in the 2006 election. Ortega also reached out to Evangelicals, who have become an increasingly influential group in Nicaraguan society that now constitutes approximately 30 percent of the population. For example, during the 2006 campaign, Ortega promised to inaugurate a monument to the Bible, which he did in 2008 (Lara 2014). Later, in the lead-up to the 2011 election, one prominent group of Evangelicals issued a public statement in support of Ortega (El Nuevo Diario 2011b).

Under the Nicaraguan Constitution, the consecutive re-election of the president is prohibited. However, in 2009, the country's Supreme Court-stacked with sympathetic judges - nullified that provision, clearing the way for Ortega to run for office again in 2011. Riding increased popularity stemming from the success of several new social programs and a relatively positive economic performance, Ortega won re-election in 2011 with 62 percent of the vote. In that same election, the FSLN also won two-thirds of the seats in the National Assembly. However, various international observers noted serious irregularities in the electoral process and its aftermath (Carter Center 2011).

During his second term, Ortega continued to forge powerful alliances not only among religious groups but also with economic elites like COSEP (Consejo Supremo de la Empresa Privada) (Spalding 2013). To appeal to the former, he continued to utilize a "reconciliation" and "family values" message (Jubb 2014), including opposition to abortion, which has been outlawed in Nicaragua since 2006 (Kampwirth 2008). To appease the latter, he attempted to maintain a stable business climate and encouraged foreign investment in high-profile projects, such as a controversial interoceanic canal, the outcome of which is still uncertain. Nicaragua's political and economic stability during this period was greatly enhanced by key regional alliances, most notably with Venezuela. ${ }^{7}$ However, this period also saw increased police crackdowns on public dissent and intimidation of journalists (Dyer 2015).

Feminist organizations in Nicaragua are highly critical of Ortega and have been the targets of repeated government attacks (CENIDH 2015; Kampwirth 2008). The tensions between the country's women's movement and the FSLN can be traced back to the party's marginalization of women's concerns during the 1980s (Heumann 
2014). These tensions, which spurred the formation of an autonomous women's movement in 1992, were further exacerbated in 1998, when President Ortega's stepdaughter, Zoilamérica Narváez, publicly accused him of sexual abuse. ${ }^{8}$ Many women who had once been active militants in the FSLN subsequently denounced Ortega and abandoned any formal affiliation with the party (Baltodano 2006).

In November 2016, Ortega won his third consecutive election, this time with his wife, Murillo, as his running mate. The election was again marked by serious irregularities, including the questionable exclusion of a major political party and high levels of voter abstention. Before the election, both the Conferencia Episcopal and COSEP criticized Ortega for his moves to create a one-party state (Mendieta 2016; Olivares 2016). By this time, however, Ortega was beholden to no one, having gained substantial control over all of Nicaragua's political institutions, including the National Assembly, the Supreme Court, and the Supreme Electoral Council.

This article builds on recent work by Jubb (2014) and Menjívar and Walsh (2016) by examining how shifts in the configuration of political power in Nicaragua, as well as broader transnational dynamics, influenced the trajectory of gender violence law (Law 779) in Nicaragua. The Ortega government's initial willingness to support a new gender violence law in 2012 can be attributed to both feminist activism and international pressure following controversial elections in 2008 and 2011. After an unexpected backlash, the Ortega government acted to mollify its religious allies by rolling back key elements of the law and sought to minimize damage to its legitimacy by emphasizing its achievements concerning gender equality and its reputation as a relatively "safe" nation.

\section{Violence Against Women AND LEGAL INSTITUTIONS IN NiCARAGUA}

Grassroots women's organizations have played a central role in legal and institutional changes to enhance state accountability and reduce gender-based violence in Nicaragua (Delgado 2003; Figueroa and Barbeyto 2014). Before 1992, for example, rape and sexual abuse in Nicaragua were defined as private offenses, and physical abuse was prosecuted only if the resulting visible injuries to the woman required 10 to 15 days to heal (Ellsberg et al. 1997). Domestic violence cases were typically settled through extrajudicial, nonbinding agreements. It was only after an arduous campaign by local feminist organizations that in 1996 the National Assembly passed Law 230, the first law to specifically address violence against women (Ellsberg et al. 1997).

Law 230 established women's right to seek protection in the case of presumed violence, expanded the definition of injurious assault to include psychological injuries, and made family ties between offender and victim an aggravating circumstance for sentencing decisions (Ellsberg et al. 1997). One woman activist interviewed for this research recalled the aftermath of that early campaign: "we carried that law [230] with us everywhere-the police were scared of us!” 
In 1993, following the example of Brazil (Santos 2005), Nicaragua established comisarías in several major cities (D'Angelo et al. 2008). Placed under the jurisdiction of the National Police, these units were staffed by trained women police officers, social workers, and women psychologists. As of 2015, there were 162 comisarias nationwide.

Feminist organizations viewed the creation of comisarias as a positive step toward reducing impunity and providing women victims with better legal and psychological support (Delgado 2003). However, they criticized the Nicaraguan government for its failure to allocate sufficient resources to these fledgling institutions. Between 2006 and 2012, for instance, comisarias received a total of 403,740 cases nationwide, an average of 187 cases per day. Yet the monthly salary of police officers working in the comisarias is only about $\$ 100$, which is less than half of the government's own estimation of the monthly cost of living in Nicaragua. In 2013, I observed firsthand how low pay, combined with a lack of basic supplies, hindered the work of police women in one comisaría in Managua (Neumann 2017). By 2016, most comisarias had been closed altogether, supposedly due to a budget shortfall.

\section{The MaKing OF LeY 779}

The first decade of the new millennium saw an alarming increase in femicides and other forms of gender violence across Mexico and Central America, due in part to the increasingly violent activity of drug cartels in the region and the complicity of state actors (Fregoso and Bejarano 2010; Menjívar 2011). These trends were evident in Nicaragua as well. The number of women killed in Nicaragua rose from 29 in 2000 to 65 in 2005 to 79 in 2008 , according to a study by the Network of Women Against Violence. In 2010, there were 33,718 domestic violence claims, an increase of more than 2,000 over the previous year, according to police reports (El Nuevo Diario 2011a).

In response, Nicaraguan feminists fought to strengthen the country's existing laws against gender violence, including explicitly criminalizing femicidio or feminicidio. Femicidio (femicide) refers to the intentional killing of women "because they are women" (Russell 1992), while feminicidio (a term coined by Mexican feminist and legislator Marcela Lagarde) extends this definition to emphasize the responsibility of the state for perpetuating these crimes against women in contexts of high impunity (Fregoso and Bejarano 2010).

In early 2010, a national organization known for its advocacy for women workers, Movimiento María Elena Cuadra (MEC), began holding meetings with women across the country to gather information about their experiences with the legal justice system. This consultation process, financed by the European Union, culminated in the presentation of a draft law and a petition with more than 12,000 signatures to the National Assembly in September 2010 (Barberena 2010). ${ }^{10}$ The introduction of the feminists' draft law in the National Assembly was made possible in part by the early support of Wilfredo Navarro, then-secretary of the National Assembly and a key member of the opposition party, the PLC. In a public statement, Navarro avowed, 
"The struggle to punish those who violate the rights of women and defend the victims of violence does not have a political color or gender. Women should not continue to be assaulted in Nicaragua" (quoted in Barberena 2010).

Almost simultaneously, key actors in the judicial system also began to express concern about rising femicide rates, and an interagency commission, led by the Supreme Court, was also formed to study the matter. In a 2011 letter addressed to the National Assembly, Chief Justice Alba Luz Ramos wrote that the commission's objective was "to create a normative body [of law], which, in accordance with international legislation, would provide greater protection to women victims of violence" (emphasis added; see Nicaraguan National Assembly Database of Laws).

The commission, whose work was underwritten by the Organization of IberoAmerican States (OEI) and the Spanish Agency for International Cooperation for Development (AECID), comprised representatives from the Public Prosecutor's Office, the National Police, the Supreme Court, the Ministry of the Family, the National Women's Institute, and the Ombudsman for Women's Rights. According to Nicaragua's legislative records, the commission found that several countries in Latin America (Brazil, Chile, El Salvador, Guatemala, and Mexico) had recently reformed or expanded their legislation on violence against women, or were in the process of doing so. This evidence-combined with the international support-proved crucial in making the case for a stronger gender violence law to the National Assembly.

The government commission's draft law was titled "Integral Law Against Violence Toward Women" and was initially presented to the National Assembly in January 2011. "With this law," commented Chief Justice Ramos, "we will transcend domestic violence and address gender-based violence" (El Nuevo Diario 2011a). Some feminist leaders told me that they believed the government's rush to draft its own law was an attempt to co-opt their own efforts, given that the feminists' proposed law had received support from some opposition figures, like Wilfredo Navarro.

The two proposals were subsequently combined into one law, but remained stalled in committee for several months. Local women's groups took to the streets to demand that the National Assembly pass the legislation, particularly targeting women deputies from the FSLN. "I hope that the women Sandinistas honor their word," one feminist commented, "because since 2010 they have been like the One Thousand and One Nights [always delaying their promises]" (La Prensa 2012). In late November 2011, several weeks after that year's controversial national elections, the National Assembly finally approved Law 779 en lo general (in principle) and, in January 2012, it was approved en lo particular (article by article) by a unanimous vote. ${ }^{11}$ President Ortega signed the law in February 2012, and Law 779 officially went into effect on June 22, 2012. Table 2 presents a summary of this legislative process. 
Table 2. Legislative Process for Law 779

\begin{tabular}{ll}
\hline \hline Date & Legislative Action \\
\hline $4 / 1 / 2010$ & $\begin{array}{l}\text { Interinstitutional Commission for the Study and Reform of Crimes of } \\
\text { Violence Against Women (CSRCVM) is formed }\end{array}$ \\
$12 / 9 / 2010$ & $\begin{array}{l}\text { Women's organizations present proposed Law Against Violence Toward } \\
\text { Women to legislative commissions }\end{array}$ \\
$2 / 24 / 2011$ & $\begin{array}{l}\text { The CSRCVM presents proposed Integral Law Against Violence Toward } \\
\text { Women to legislative commissions }\end{array}$ \\
$7 / 14 / 2011$ & $\begin{array}{l}\text { Revised and approved draft law sent to president of National Assembly } \\
11 / 29 / 2011\end{array}$ \\
$\begin{array}{l}\text { National Assembly approves in principle Law 779, Integral Law Against } \\
\text { Violence Toward Women, and reforms of the penal code }\end{array}$ \\
National Assembly unanimously approves Law 779 article by article \\
$6 / 20 / 2012$ & $\begin{array}{l}\text { President Ortega signs Law 779 } \\
\text { Law 779 goes into effect }\end{array}$ \\
\hline \hline
\end{tabular}

\section{The Content of Ley 779}

Law 779 introduced a number of new and important provisions. First, it codified femicide as a crime with a maximum penalty of 25 years' imprisonment. ${ }^{12}$ Second, it established penalties for other types of violence occurring in both the private and public spheres that previous laws had not included, such as intimidation, harassment, patrimonial violence, labor violence, and state negligence. Third, it expanded the pretrial measures available to protect women deemed to be in high-risk situations. For example, the police were granted authority to remove the accused from the home if a woman's life was threatened, and prosecutors could issue restraining orders and require the accused to pay child support, among other options. These measures could be implemented for up to 20 days after a charge was made and extended by a judge at the request of a state attorney.

Fourth, and most controversial, the law eliminated the option of mediation (nonbinding agreements between the woman and the accused, commonly facilitated by police at the comisaría). Fifth, it established specialized courts for gender violence cases, presided over by trained judges. More broadly, the law made explicit that violence against women was rooted in the "unequal power relations between men and women." Echoing the language of Belém do Pará, Law 779 clearly articulated the state's obligation to protect women's rights, including the right to a life free of violence (Articles 2, 3, and 8).

Local feminists celebrated the passage of Law 779 and immediately began an intensive education campaign to inform women about their new rights. One activist called the law a "light of hope" for women (fieldnotes 8/2014). During the summer of 2012, women's groups organized a number of workshops about Law 779. In one such session, in a low-income barrio in east Managua, a group of women braved the 
rain with their toddlers to attend a charla where a woman legal advocate facilitated a discussion about how Law 779 would be applied. Women expressed excitement ("finally there is a law for us") but also reservations about how men would react ("they say it's harsh") (fieldnotes 7/2012). Feminists saw workshops like this as a way to generate momentum for Law 779.

Yet on the day the law took effect (June 22, 2012), the National Assembly had not yet allocated the funds needed to implement significant portions of Law 779, including appointing 40 new special prosecutors and hiring 200 new psychologists and forensic lab specialists (El Nuevo Diario 2013c). That very same day, dozens of women waving lavender flags gathered outside the Supreme Court to demand "the full implementation of the law within 100 days." Reporters clustered around Luz Marina Torres of the women's collective 8 de Marzo as she read a statement on behalf of the women's movement. "This law is the culmination of four decades of feminist activism," Torres declared (fieldnotes 6/2012). Throughout the summer, women's organizations continued to protest, often shutting down major thoroughfares throughout Managua. Common slogans included, "Castigo para los agresores, justicia para las mujeres" (punishment for aggressors, justice for women), "machismo mata" (sexism kills), and "el cuerpo de las mujeres se respeta" (respect women's bodies) (fieldnotes 7/2012). Street banners were strategically placed at major intersections, including one that read, "Law 779 without a budget is like gallo pinto [a common rice and bean dish] without the beans" (fieldnotes 6/2012).

Despite the feminist pressure, implementation of Law 779 was slow and uneven. In late July 2012, only 2 specialized courts were operating in Managua. One year later, in June 2013, there were 13 specialized courts: 6 in Managua and 7 in the rest of the country (Lara 2013). Just 24 prosecutors were available for gender crimes, and they had overseen 800 cases the previous year. At the same time, there were only 27 offices of forensic medicine, housing 100 total analysts responsible for covering Nicaragua's 153 municipalities (El Nuevo Diario 2013c). According to Julio Centeno, Nicaragua's attorney general, each specialized court would cost USD $\$ 60,000$ a year (Vásquez 2012a). The state's inaction led some leaders in the women’s movement to call Law 779 a "dead law" (Vásquez 2012b).

\section{THE BACKLASH AgaINST THE LAW}

Opposition to Law 779 began even before its implementation and arose across the denominational spectrum (both Catholic and Evangelical), as well as among men's associations and some local attorneys. ${ }^{13}$ Opponents of the law offered three main criticisms: the law would destroy the family, it would cause more violence, and it violated the constitutional principle of equal protection by discriminating against men.

Religious leaders were most concerned about the effect of Law 779 on family structure. Rev. Saturino Cerrato, president of the local Assembly of God Church, claimed that the Law 779 would "destroy marriage and the family" because it eliminated the possibility of mediation between the victim and the accused (Sirias and 
Picón 2013). He claimed that Law 779 violated the principle of "innocent until proven guilty." Law 779 was also opposed by the local Episcopal Conference, which called it "an attack on evangelical values" (Martínez 2013). Msgr. Silvio Fonseca, from the Archdiocese of Managua, stated, "[Law 779] tilts the balance toward women and leaves men unprotected." Another bishop went so far as to call Law 779 "the new number of the beast," a biblical reference to the devil (El Nuevo Diario 2013b).

In July 2012 (less than one month after the law went into effect), a formal legal challenge to the constitutionality of Law 779 was filed with the Nicaraguan Supreme Court by the Association of Democratic Lawyers (ADANIC). By prohibiting mediation, ADANIC claimed, Law 779 violated the constitutional principle of equality under the law. The president of ADANIC, Danilo Martínez, published various opinion pieces arguing that "legislators should have an integral perspective on violence, not a gender perspective, because violence is not exclusive to the male sex" (quoted in Gallegos 2013). ADANIC also critiqued the law on logistical grounds, pointing out that Nicaragua's court and prison systems were not equipped to deal with the surge of convictions that Law 779 would probably generate. ${ }^{14}$ As headlines about the rising number of incarcerated men filled the newspapers in 2013, feminist leaders reiterated, "The point is not to put men in jail, it's that we as women live free of violence; only the punitive part of the law gets talked about, but no one talks about the prevention part" (El Nuevo Diario 2013a). ${ }^{15}$

In the midst of this controversy, one of the few elected officials to openly ally himself with the women's movement was Sandinista legislator Carlos Emilio López. "We should not make reforms that weaken women's rights," he argued. "Human rights are progressive. Once you've recognized a human right, you can't go backwards . . . what needs to be reformed is the national consciousness" (Picón 2013). Chief Justice Alba Luz Ramos also issued statements of support for the lawalthough she did not discount the possibility that Law 779 could be reformed. Chief Justice Ramos encouraged women's organizations to maintain pressure on elected officials to fully implement the law.

Women responded by once again taking to the streets during the summer of 2013 to defend Law 779, and especially to oppose the possibility of reintroducing mediation. Feminist organizations that strongly opposed mediation pointed to research showing that at least 30 percent of documented cases of mediation agreements ultimately led to femicide (Solís 2013). Feminist leaders also pointed out that mediation is not a neutral encounter, because women may feel coerced into agreeing to whatever terms are preferred by the accused in order to avoid future violence. As a representative of the Women's Network Against Violence explained, "when a woman files a complaint, it's because her life is at risk . . . a victim is not in the same conditions to negotiate with her aggressor" (Vásquez and Romero 2013). Organizations like Amnesty International also spoke out about the repercussions of reforming the law, asserting that "what fractures families is the violence perpetrated against women and children, not legislation designed to help victims escape this violence" (Amnesty International 2013). 
After months of contentious public debate, in August 2013 the Supreme Court issued Sentence 18, upholding Law 779 as constitutional. ${ }^{16}$ However, the court called on the National Assembly to reform the law to reintroduce the option of mediation. According to the court, mediation should be permitted only with a woman's consent and in any case involving a first offense punishable with less than a five-year sentence. Despite the opposition of local feminists and international human rights organizations, just 14 months after Law 779 went into effect, the National Assembly overwhelmingly approved a modified law (83 in favor, 4 opposed, 1 abstention), which reintegrated mediation for first and minor offenses.

The amended law permitted mediation when the accused had no prior legal offenses, the alleged crime was classified as a "minor offense" with a carceral penalty of five years or less, the women agreed of her own volition to mediate, no previous mediation had occurred between the two parties, and mediation was conducted and documented by the attorney general's office or a judge. ${ }^{17}$ Mediation between the two parties was permitted at any stage of the process, up until the moment of sentencing.

\section{Presidential Decree DERAILS THE LAW}

The contentious politics surrounding Law 779 did not end with the reform in September 2013. Longstanding critics of the law-both secular and religiouscontinued to speak out; complaints ranged from the issues with overcrowded prisons due to increasing numbers of men convicted under Law 779 to the nowfamiliar handwringing over the so-called destruction of the family (Jubb 2014). Women's organizations continued to protest the use of mediation in gender-based violence cases throughout 2014 via street protests as well as petitions.

In April 2014, Amnesty International reiterated that the amendments to Law 779 would "weaken the protections for victims, facilitate impunity for abusers and are contrary to international and national obligations to protect women's rights" (UNGA 2014). When the United Nations Human Rights Council (UNHRC) convened in May 2014, member states urged the Nicaraguan delegation to reconsider the amendments to Law 779, particularly with regard to mediation (UNGA 2014). In making these statements, Amnesty International and UNHRC sought to hold the state accountable for its international commitments to address violence against women. Local feminist organizations saw these interventions by human rights groups as highly significant because the state had failed to meet its obligations under the Belém do Pará Convention to protect and defend women's rights. However, Nicaraguan officials brushed aside the UNHRC's concerns. The international criticism of the government's modifications to Law 779 was clearly not considered a serious threat to the state's legitimacy. ${ }^{18}$

As the controversy over mediation continued to swirl, another debate concerning Law 779 emerged over the definition of femicide. In July 2014, a Nicaraguan Supreme Court justice abruptly suggested that "if there's no partner relationship, there's no reason it should be a femicide” (Vásquez 2014). This 
statement coincided with the release of a police report stating that 18 femicides had been committed during the first half of 2014, a figure far lower than the 47 cases documented by local women's organizations (Membreño 2014). National Police commissioner Francisco Díaz declared, "Our country continues to be one of the safest in Latin America, and the safest country in Central America" (Romero 2014).

These statements foreshadowed the second round of substantial changes to Law 779. In late July 2014, President Ortega issued two special decrees related to the law (Decrees 42-2014 and 43-2014). The regulations contained in the decrees significantly altered the purpose and legal framework of the law. They shifted the objective of Law 779 to "strengthen[ing] Nicaraguan families ... [and] a culture of familial harmony" (Decree 42-2014, Article 1). They reduced the scope of femicide (which originally encompassed the killing of women in either the public or private sphere) to include only the killings of women committed in the home in the context of preexisting relationships. They also shifted the responsibility for implementing Law 779 from an interinstitutional commission to the Ministry of the Family. The decrees also mandated the establishment of neighborhood-based counseling (led by religious and political leaders) for women victims as a first step to resolving "family conflict" before placing a legal complaint. Cases unresolved at the neighborhood level would be referred to the Ministry of the Family and only as a last resort to the comisarias (Decree 42-2014, Article 10).

The presidential decrees fundamentally altered both the content and intent of the original law_-and explicitly contradicted the Belém do Pará Convention ratified by Nicaragua. Yet some members of the Supreme Court publicly defended the new regulations. Chief Justice Ramos argued that the changes in the definition of femicide were irrelevant because crimes not prosecuted as femicides would proceed under the charge of murder, which carried just as severe a penalty (Jiménez 2014). These remarks were a clear departure from earlier statements Justice Ramos had made justifying the constitutionality of the law and its importance as an expression of Nicaragua's adherence to the Belém do Pará Convention.

Local feminist groups were outraged, calling the decree "atrocious" and a "monstrosity" (fieldnotes 8/14/2014). At a press conference just two weeks after the decretazo (a term used by some activists to refer to the presidential decrees), one local feminist leader remarked, "This is how machismo and authoritarianism manifest themselves itself in the executive branch. Above the political constitution, international conventions, the national legal framework, and institutional commitment contained in the law" (fieldnotes 8/14/2014). At a meeting of a gender roundtable, one woman commented, "The little that we've won, we're losing." "How can a decree be above the law?" another pondered aloud. "This state is perverse," said a third (fieldnotes 8/21/2014). One cartoon published in La Prensa that month dramatically captured the sentiment of local feminists: it featured President Ortega holding a baseball bat and standing over a tombstone labeled 779, saying, "I killed her because she was mine."

Feminist organizations took their concerns from crowded conference rooms into the muggy streets of Managua. One August afternoon in 2014, shortly before 
dusk, I joined dozens of women gathered at an iconic rotunda near the capital's old commercial center to march toward the National Assembly. Dressed in black and carrying small candles and posters with photos of women victims, they walked in single file down the center of a historic boulevard that leads to the city's recently redeveloped lakefront. Yet as we approached a major intersection, we encountered a line of men, including police officers and others dressed in dark blue polo shirts and Sandinista baseball caps, blocking our way. The women clustered in small groups talking in hushed tones about what might happen; several discussed the likelihood that President Ortega himself had ordered the men to prevent the march from reaching its destination. Meanwhile, women leaders of the march vehemently argued with the police, trying to persuade them to let us through. "Why can't we pass through? We have the right to freely mobilize," one woman shouted. "This is proof that our rights are being violated!" But the police stood their ground and refused to let us march any further. After about 15 minutes, we turned around (fieldnotes 8/14/2014).

Protests continued throughout the fall of 2014, though more sporadically. Most of the feminist leaders' energy turned to designing workshops for women's groups around the country to analyze the newest changes to Law 779 and how to fight them. At several events I attended, local feminist lawyers explained to the women in attendance that the presidential decree superseded the legal authority granted to the president. Feminist leaders argued that Ortega's decrees contradicted international conventions on gender-based violence and that the implementation of a family counseling system would only further complicate the legal process for women victims. These events served to generate new ideas, as well as to provide a venue for collecting signatures for petitions challenging the constitutionality of the presidential decree. As one woman put it, "in the face of illegality, we have to use legal arguments."

On September 30, 2014, feminist organizations organized another rally in front of the Supreme Court in Managua, where they presented their official petitions for judicial review of the decrees. ${ }^{19}$ The very next day, I attended the inauguration ceremony for the Ministry of the Family's new counseling office at a comisaria in Managua. When I arrived at the comisaria that morning, the formerly tall grass surrounding the building had been freshly mowed, and colorful banners with slogans such as "In love there is no fear" were being hung under a small white tent nearby. In attendance were representatives from the National Police, the Women's Commissariat, the Ministry of the Family, and a handful of women volunteers who work with the comisarias. One official welcomed everyone to the "comisaria of the family and the community" (a clear discursive change from its official institutional name, Comisaria of Women and Children).

After a short series of speeches, the woman captain of the comisaria invited those in attendance to come inside and tour the comisaria's updated facilities, which had been recently painted with bright green and peach hues and decorated with balloons. One wall featured a series of posters celebrating the family. One poster said, "A family united in the love of Christ lasts forever. Give God control of your 
family today and always." Another featured a black and white triangular drawing likening the ideal relationship between father, mother, and children to the Father, the Son, and the Holy Spirit, known in Christian theology as the Holy Trinity.

Several weeks after the inauguration of the family counseling office at the comisaria in Managua, the World Economic Forum (2014) released its annual Gender Gap Report, ranking Nicaragua sixth in the world behind Iceland, Finland, Norway, Denmark, and Sweden. The Gender Gap Report compares disparities between men and women in four areas: economic opportunities, education, health and life expectancy, and political participation. While women's rights advocates were surprised by this ranking, President Ortega heralded the news as confirmation of his government's apparently successful efforts to promote gender equality, maintaining the illusion that Nicaragua is safer and more progressive than most of its Central American neighbors. International media coverage of the Gender Gap Report was also generally favorable to Nicaragua, drawing attention away from the serious rollbacks to Law 779 and women's rights more generally. Meanwhile, according to the United Nations' Gender Inequality Index, Nicaragua ranked 90th in 2014 and has been steadily falling since then. Neither of these studies includes any specific measure of gender violence, however.

\section{CONClusions}

From 2010 to 2012, the Supreme Court and the National Assembly took clear steps to advance women's legal rights in Nicaragua by proposing, approving, and defending Law 779. However, the tide turned in 2013 with the mobilization of conservative opposition to the law, leading to an abrupt about-face by the Ortega administration and later, by the Supreme Court and elected officials. The swiftness of this turn was enabled, to a large extent, by the consolidation of power in the hands of President Ortega and his allies. Ortega's popular support and high level of institutional control have made him relatively immune from international pressures on a range of issues, including violence against women.

The Nicaraguan case demonstrates that without tangible international accountability mechanisms, local political conditions take on a central role in the passage and implementation of gender-based violence laws. Although a combination of external and internal pressure was momentarily able to pierce a seemingly impervious wall of impunity, almost immediately, these gains were overturned by a sustained backlash from conservative religious groups, resulting in a series of legislative and executive actions that severely curtailed legal protections for women. Facing a new wave of criticism from both local feminists and global human rights organizations, the Ortega government sought to reframe the issue by focusing on its achievements related to gender equality and its reputation in Central America as a relatively safe nation. In other words, it sought to maintain its legitimacy, but on different grounds.

The trajectory of gender violence law in Nicaragua raises broader questions about the relative effectiveness of legal activism (defined as the pursuit of legal change). Legal strategies have been utilized by feminist organizations worldwide to 
address the problem of gender-based violence (Friedman 2009). Research has shown that such advocacy is crucial to expanding women's rights (Htun and Weldon 2012). Yet the foregoing discussion also illustrates the fragility of these gains in contexts characterized by a high concentration of political power.

Under such circumstances, the current infrastructure of "global governance" (Finkelstein 1995; Meyer and Prugl 1999) is far less influential in motivating states to act to protect women's rights than it is in other issues. Although some scholars have argued that state legitimacy rests on (at least discursive, if not practical) adherence to global agreements, the case of Law 779 in Nicaragua highlights some of the limitations of global arena pressures on the issue of gender violence. As mentioned at the outset, one of the most significant issues is that there are few, if any, tangible consequences for states that fail to uphold international conventions on genderbased violence.

This lack of state accountability to address the problem of violence against women stands in stark contrast to how global institutions handle other issues, like defaulting on loans and violating trade agreements. When governments fail to repay their international creditors, they become economic pariahs and are denied further monetary assistance. But when states fail to uphold the most basic of rights for women (the right to a life free of violence), they are often subjected to little more than a strongly worded letter (UNGA 2014). Therefore, governments' legal and policy failures on gender violence rarely constitute a serious challenge to state legitimacy. Given these findings, the gendered hierarchy of concerns within different supranational institutions merits more attention when we seek to understand state action and inaction on gender violence in Latin America and elsewhere. In the meantime, more than two decades after the ratification of the Belém do Pará Convention, ensuring women's right to a life free of violence remains as elusive as ever.

\section{NOTES}

My sincere appreciation to Megan Neely, the Rapaport Center for Human Rights and Justice Working Paper Series, and three anonymous reviewers for LAPS for their generous feedback on earlier versions of this article. Funding for this research was provided in part by the Teresa Lozano Long Institute for Latin American Studies at the University of Texas at Austin. All translations are by the author.

1. According to Nicaragua's National Police, the country's homicide rate in 2015 was 8.6 per 100,000, the lowest rate in Central America and the third-lowest in Latin America. The Global Peace Index (2015) also ranks Nicaragua safer than Guatemala, El Salvador, and Honduras. However, the GPI's most recent rankings show a rise in violent crime in Nicaragua. The index does not include an indicator for violence against women.

2. The Belém do Pará Convention is seen as "hard law" because it contains specific accountability mechanisms for individual or organizational appeal when ratifying states fail to comply with their responsibilities under the convention (Friedman 2009).

3. In 2000, an optional protocol was added to CEDAW to allow individual women or groups to submit claims of violations of rights protected under the convention. Nicaragua is not a signatory to this protocol. 
4. Daniel Ortega won the presidential election in November 2006 with 38 percent of the vote. Before the election, the electoral law was changed to lower the threshold for victory from 40 percent to 35 percent and a 5 percent margin.

5. One of the long-term effects of the pact was a substantial weakening of the independence of the National Assembly. FSLN deputies who do not vote with President Ortega risk being marginalized from the party or losing their seats in future elections.

6. In the 2006 election, the PLC candidate won 25 percent of the vote and the ALN candidate won 23 percent.

7. The economic crisis in Venezuela may partially explain why President Ortega responded so quickly to conservative and religious pressure to modify Law 779. Many of the country's social programs have been subsidized in the past by Venezuelan aid.

8. Ortega has never faced formal charges for the alleged abuse because the Supreme Court granted him immunity as a member of the legislature (Narváez 2002).

9. Much of the early funding for comisarias came from international cooperation; however, according to the Women's Ombudsman Office, in 2013, 80 percent of the comisaria budget came from the Nicaraguan government.

10. The project was called "Constructing Strategies and Actions to Confront Feminicide and Gender-Based Violence Against Women in Central America" and was implemented by the Cristiana Romero Initiative of Germany (Barberena 2010).

11. At the time of the first vote (November 2011), the FSLN held 38 seats out of 92 total in the National Assembly. At the time of the second vote (January 2012), the FSLN held 62 seats.

12. Under Law 779, a woman's death would be considered a femicide if the act were committed in the public or private sphere under any of the following circumstances: as part of an unsuccessful attempt to establish or reestablish intimacy with the victim; if there were any kind of familial, work, intimate, educational, or guardianship relationship with the victim; if the woman's death were a result of repeated violence; if it involved the sexual degradation of the women's body (e.g., genital mutilation); if there were evidence of misogyny; if it were a result of a group ritual or gang activity; or if the act were committed in the presence of the victim's children.

13. Not all Evangelicals in Nicaragua opposed Law 779. During my fieldwork I attended a daylong seminar sponsored by one network of progressive Evangelical churches to help pastors better understand the law and how to support women in their congregations and communities (Romero 2013).

14. Prison overcrowding is a serious issue in Nicaragua. The country's 8 prisons have a total inmate capacity of 4,300, but the 2014 detainee population was 9,801 (UNGA 2014).

15. According to the Nicaraguan National Police, between June 2012 and April 2013, 696 men were convicted under Law 779 (El Nuevo Diario 2013a).

16. Before the court's official ruling, the president of the Supreme Court accused some of its members of publicly inciting opposition to the law by suggesting its unconstitutionality (Vásquez 2013).

17. The five-year carceral designation means that some crimes involving bodily harm, threats, and child abduction, among others, were now eligible for mediation (Amnesty International 2013).

18. Nicaraguan government representatives have also failed to appear before the InterAmerican Human Rights Commission on four separate occasions, the most recent a hearing in September 2017 on the ongoing threats to women activists in Nicaragua.

19. As of February 2018, the Nicaraguan Supreme Court had offered no response to the feminists' petitions. 


\section{REFERENCES}

Amenta, Edwin, Neil Caren, Elizabeth Chiarello, and Yang Su. 2010. The Political Consequences of Social Movements. Annual Review of Sociology 36: 287-307.

Amnesty International. 2013. Nicaragua: Authorities Should Support Law Protecting Women from Violence. May 3. https://www.amnesty.org/en/documents/PRE01/219/ 2013/en

Baltodano, Monica. 2006. Why We Joined the Movement to Rescue Sandinismo. Envio 297 (April). http://www.envio.org.ni/articulo/3250

Barberena, Edgard. 2010. Más de 12 mil firmas respaldan proyecto de ley a favor de mujeres. El Nuevo Diario, October 20. https://www.elnuevodiario.com.ni/nacionales/86155mas-12-mil-firmas-respaldan-proyecto-ley-favor-muj/

Bernal Sarmiento, Camilo, Miguel Lorente Acosta, Françoise Roth, and Margarita Zambrano. 2014. Latin American Model Protocol for the Investigation of Gender-Related Killings of Women (Femicide/Feminicide). United Nations High Commissioner for Human Rights. http://endviolence.un.org/pdf/LatinAmericanProtocolForInvestigation OfFemicide.pdf

Bunch, Charlotte. 1990. Women's Rights as Human Rights: Toward a Re-vision of Human Rights. Human Rights Quarterly 12: 486-98.

Bunch, Charlotte, and Susana Fried. 1996. Beijing 1995: Moving Women's Human Rights from Margin to Center. Signs 22, 1: 200-204.

Carter Center. 2011. The November 2011 Elections in Nicaragua. Atlanta: Carter Center. https://www.cartercenter.org/resources/pdfs/peace/americas/nicaragua_2011_report_ post.pdf

Centro Nicaragüense por los Derechos Humanos (CENIDH). 2015. Derechos humanos en Nicaragua. Managua: CENIDH. http://www.cenidh.org/media/documents/docfile/ Informe_CENIDH_Final2015WEb-2.pdf

Charlesworth, Hilary. 1994. What are "Women's International Human Rights"? In Human Rights of Women: National and International Perspectives, ed. Rebecca J. Cook. Philadelphia: University of Pennsylvania Press. 58-84.

D’Angelo, Almachiara, Nadine Jubb, and Yamileth Medina. 2008. Mapeo de las comisarías de la mujer y la niñez en Nicaragua. Managua: PATH. http://enlaceacademico.ucr.ac. $\mathrm{cr} /$ sites/default/files/publicaciones/MAPEO_Nicaragua_Comisarias.pdf

Delgado, Violeta. 2003. The Experiences and Achievements of the Women's Network Against Violence. Envio 261 (April). http://www.envio.org.ni/articulo/2083

Desai, Manisha. 2005. Transnationalism: The Face of Feminist Politics Post-Beijing. International Social Science Journal 57, 184: 319-30.

Dyer, Zach. 2015. Nicaragua Canal Project Surrounded by Air of Intimidation, Opponents Say. Tico Times, June 10. www.ticotimes.net/2015/06/10/nicaragua-canal-projectsurrounded-air-intimidation-opponents-say

Economic Commission for Latin America and the Caribbean (ECLAC). 2014. ECLAC Calls for End of Inequalities that Contribute to Violence Against Women. Press release. November 7. www.cepal.org/en/pressreleases/eclac-calls-end-inequalities-contributeviolence-against-women

Ellsberg, Mary, Jerker Liljestrand, and Anna Winkvist. 1997. The Nicaraguan Network of Women Against Violence: Using Research and Action for Change. Reproductive Health Matters 10: 82-92. 
Ferree, Myra Marx, and Aili Mari Tripp, eds. 2006. Global Feminism: Transnational Women's Activism, Organizing, and Human Rights. New York: New York University Press.

Figueroa, Dolores, and Arelly Barbeyto. 2014. Indigenous, Mestizo and Afro-Descendent

Women Against Violence: Building Interethnic Alliances in the Context of Regional Autonomy. Bulletin of Latin American Research 33: 305-18.

Finkelstein, Lawrence. 1995. What is Global Governance? Global Governance 1, 3: 367-72.

Franceschet, Susan. 2010. Explaining Domestic Violence Policy Outcomes in Chile and Argentina. Latin American Politics and Society 52, 3: 1-29.

Fregoso, Rosa Linda, and Cynthia Bejarano, eds. 2010. Terrorizing Women: Feminicide in the Americas. Durham: Duke University Press.

Friedman, Elisabeth Jay. 2003. Gendering the Agenda: The Impact of the Transnational Women's Rights Movement at the UN Conferences of the 1990s. Women's Studies International Forum 26, 4: 313-31.

2009. Re(gion)alizing Women’s Human Rights in Latin America. Politics \& Gender 5: 349-75.

Gallegos, Noel Amilcar. 2013. Abogados contra Ley 779. La Prensa, May 14. www.laprensa.com.ni/2013/05/14/politica/146550-abogados-contra-ley-779

Grewal, Inderpal. 1999. "Women’s Rights as Human Rights”: Feminist Practices, Global Feminism, and Human Rights Regimes in Transnationality. Citizenship Studies 3, 3: $337-54$.

Heumann, Silke. 2014. Gender, Sexuality, and Politics: Rethinking the Relationship Between Feminism and Sandinismo in Nicaragua. Social Politics 21, 2: 290-314.

Hoyt, Katherine. 2004. Parties and Pacts in Contemporary Nicaragua. In Undoing Democracy: The Politics of Electoral Caudillismo, ed. David Close and Kalowatie Deonandan. Lanham: Lexington Books. 17-42.

Htun, Mala, and S. Laurel Weldon. 2012. The Civic Origins of Progressive Policy Change: Combating Violence Against Women in Global Perspective, 1975-2005. American Political Science Review 106, 3: 548-69.

Jiménez, Magdalena. 2014. Si no es femicidio, es asesinato. Poder Judicial de Nicaragua, August 14. Nicaragua: Dirección General de Comunicación. www.poderjudicial.gob.ni/ prensa/notas_prensa_detalle.asp?id_noticia $=4962$

Joachim, Jutta M. 2007. Agenda Setting, the UN, and NGOs: Gender Violence and Reproductive Rights. Washington, DC: Georgetown University Press.

Jubb, Nadine. 2014. Love, Family Values and Reconciliation for All, but What About Rights, Justice and Citizenship for Women? The FSLN, the Women's Movement, and Violence Against Women in Nicaragua. Bulletin of Latin American Research 33, 3: 289-304.

Kampwirth, Karen. 2008. Abortion, Antifeminism, and the Return of Daniel Ortega in Nicaragua: Leftist Politics? Latin American Perspectives 35, 6: 122-36.

- 2011. Latin America's New Left and the Politics of Gender: Lessons from Nicaragua. New York: Springer.

Keck, Margaret, and Kathryn Sikkink. 1998. Activists Beyond Borders: Advocacy Networks in International Politics. Ithaca: Cornell University Press.

Kitschelt, Herbert. 1986. Political Opportunity Structures and Political Protest: Anti-Nuclear Movements in Four Democracies. British Journal of Political Science 16, 1: 57-85.

Lara, Rafael. 2013. Lento pero seguro avance de Ley 779. El Nuevo Diario, July 23. www.elnuevodiario.com.ni/nacionales/292405-lento-seguro-avance-ley-779

. 2014. Remodelarán parque La Biblia. El Nuevo Diario, September 30. www.elnuevo diario.com.ni/managua/331133-remodelaran-parque-biblia/ 
Martí i Puig, Salvador, and Claire Wright. 2010. The Adaptation of the FSLN: Daniel Ortega's Leadership and Democracy in Nicaragua. Latin American Politics and Society 52, 4: 79-106.

Martínez, Saul. 2013. Analizan Ley 779 y el Código de Familia. La Prensa, July 24. www. laprensa.com.ni/2013/07/24/politica/155939-analizan-ley-779-y-el-codigo-de-familia

Membreño, Cinthia. 2014. Policía minimiza femicidios. Confidencial (Managua), July 5. www.confidencial.com.ni/archivos/articulo/18310/policia-minimiza-femicidios

Mendieta, Emiliano. 2016. "Partido único, nocivo para el país," dicen obispos de Nicaragua. La Prensa, June 14. www.laprensa.com.ni/2016/06/14 /politica/2052022-fuertecomunicado-de-obispos

Menjívar, Cecilia. 2011. Enduring Violence: Ladina Women's Lives in Guatemala. Berkeley: University of California Press.

Merry, Sally. E. 2006. Human Rights and Gender Violence: Translating International Law into Local Justice. Chicago: University of Chicago Press.

Meyer, Mary K., and Elisabeth Prugl, eds. 1999. Gender Politics in Global Governance. Lanham: Rowman and Littlefield.

Narváez, Zoilamérica. 2002. Case 12,230: Zoilamérica Narváez vs. the Nicaraguan State. Envio 248 (March). http://www.envio.org.ni/articulo/1567

Neumann, Pamela. 2017. When Laws Are Not Enough: Violence Against Women and Bureaucratic Practice in Nicaragua. Social Forces 95, 3: 1105-25.

Nicaraguan National Assembly. Database of Laws. 2011. Ley integral contra la violencia hacia la mujer. Letter from Chief Justice Alba Luz Ramos. January 31. http://legislacion.asamblea.gob.ni/SILEG/Iniciativas.nsf/0/8f45bac34395458c062578320075bde4? OpenDocument $\&$ ExpandSection $=1 \&$ TableRow $=3.0 \# 3$

El Nuevo Diario (Managua). 2011a. Un flagelo llamado feminicidio. January 9. www.elnuevodiario.com.ni/especiales/92010-flagelo-llamado-feminicidio/

— 2011b. Sector evangélico respalda candidatura de Ortega. October 31. www. elnuevodiario.com.ni/politica/231698-sector-evangelico-respalda-candidatura-ortega/

—. 2013a. 696 Hombres condenados bajo la Ley 779. April 29. www.elnuevodiario. com.ni/especiales/284578-696-hombres-condenados-ley-779/

2013b. Obispo Sándigo propone revisión de Ley 779. May 10. www.elnuevodiario. com.ni/nacionales/285636-obispo-sandigo-propone-revision-ley-779/

2013c. Nicaragua tiene déficit de fiscales y de forenses. July 15. www.elnuevodiario. com.ni/nacionales/291680-nicaragua-tiene-deficit-fiscales-forenses/

Olivares, Ivan. 2016. Cosep: hay un grave riesgo económico. Confidencial, June 20. https:// confidencial.com.ni/cosep-grave-riesgo-economico/

Picón, Gloria. 2013. Reforma a Ley 779 es improcedente. La Prensa, June 20. www.laprensa. com.ni/2013/06/20/politica/151541-reforma-a-ley-779-es-improcedente

La Prensa (Managua). 2012. Cientos de mujeres exigen en Nicaragua ley que las proteja de la violencia. January 24. www.laprensa.com.ni/2012/01/24/internacionales/88258cientos-de-mujeres-exigen-en-nicaragua-ley-que-las-proteja-de-la-violencia

Romero, Elizabeth. 2013. Capacitan pastores sobre Ley 779. La Prensa, July 1. www. laprensa.com.ni/2013/07/01/nacionales/152989-capacitan-a-pastores-sobre-la-ley779 .

2014. Para la policía, solo son 18. La Prensa, July 5. www.laprensa.com.ni/2014/07/ 05/nacionales/201873-para-la-policia-solo-son-18

Russell, Diana. 1992. Preface. In Femicide: The Politics of Woman Killing, ed. Jill Radford and Russell. New York: Twayne. xi-xv. 
Sagot, Montserrat. 2005. The Critical Path of Women Affected by Family Violence in Latin America. Violence Against Women 11, 10: 1292-1318.

Santos, Cecilia. 2005. Women's Police Stations: Gender, Violence and Justice in Säo Paulo, Brazil. New York: Palgrave Macmillan.

Sirias, Tania, and Gloria Picón. 2013. Ley destruye matrimonios. La Prensa, April 19. www.laprensa.com.ni/2013/04/19/politica/143128-ley-destruye-matrimonios

Solís, Azahalea. 2013. The Reform of Law 779 Sends Society a Very Negative Message. Envio 388 (November). http://www.envio.org.ni/articulo/4783

Spalding, Rose J. 2013. Business and State Relations in Post-Revolutionary Nicaragua: Elite Realignment and the New Strategy of Collaboration. Paper prepared for the Central American Elites Project, FLACSO-Costa Rica, June 29. https:/www.american.edu/ clals/upload/Spalding_Business_and_State_in_Nicaragua.pdf

Staudt, Kathleen. 2008. Violence and Activism at the Border: Gender, Fear, and Everyday Life in Ciudad Juárez. Austin: University of Texas Press.

Sternbach, Nancy, Marysa Navarro-Aranguren, Patricia Chuchryk, and Sonia E. Álvarez. 1992. Feminisms in Latin America: From Bogotá to San Bernardo. Signs 17, 2: 393434.

United Nations General Assembly (UNGA). Human Rights Council. 2014. Report of the Working Group on the Universal Periodic Review. July 1. http://www2.ohchr.org/english/bodies/hrcouncil/docs/14session/Draftreport14thHRC.pdf

Vásquez, Martha. 2012a. Hay ley pero falta dinero. La Prensa, June 19. www.laprensa.com. ni/2012/06/19/nacionales/105550-hay-ley-pero-falta-el-dinero

—. 2012b. Es como niño prematuro. La Prensa, July 17. www.laprensa.com.ni/2012/ 07/17/nacionales/108889-es-como-nino-prematuro

2013. Recurren contra Ley 779 ante CSJ. La Prensa, March 9. www.laprensa.com. ni/2013/03/09/nacionales/137509-recurren-contra-ley-779-ante-csj

- 2014. Si no hay relación de pareja, no tiene porqué ser femicidio. La Prensa, July 15. https:/www.laprensa.com.ni/2014/07/15/nacionales/203384-si-no-hay-relacion-depareja-no-tiene-porque-ser-femicidio

Vásquez, Martha, and Elizabeth Romero. 2013. Aplicarán mediación en ley 779. La Prensa, April 30. https://www.laprensa.com.ni/2013/04/30/nacionales/144673-aplicaranmediacion-en-ley-779

Walsh, Shannon Drysdale, and Cecilia Menjívar. 2016. "What Guarantees Do We Have?" Legal Tolls and Persistent Impunity for Feminicide in Guatemala. Latin American Politics and Society 58, 4: 31-55.

World Economic Forum. 2014. The Global Gender Gap Report. Geneva, Switzerland. http://www3.weforum.org/docs/GGGR14/GGGR_CompleteReport_2014.pdf 